\title{
Pengaruh Audit Operasional Fungsi Pemasaran dan Pengendalian Internal terhadap Efektivitas Pelayanan Konsumen PT. Kembang Joyo Sriwijaya
}

\author{
J.A. Putritamara*, Zaenal Fanani, U. Wisaptiningsih, N. Febrianto \\ Sosial Ekonomi Peternakan Fakultas Peternakan, Universitas Brawijaya \\ Jl. Veteran. Malang. Telp. 0341-553513 \\ *Email korespondensi: jaisyap@ub.ac.id
}

(Diterima: 26-06-2019; disetujui 10-08-2019)

\begin{abstract}
ABSTRAK
Tujuan penelitian menganalisis model struktural dari pengaruh audit operasional fungsi pemasaran dan pengendalian internal terhadap efektivitas pelayanan konsumen. Responden dalam penelitian ini adalah Manajer pemasaran dan staff di wilayah Malang serta Palembang sebanyak 30 responden dan divisi administrasi dalam recording serta auditor dan auditee (yang tidak termasuk kategori responden 30 orang) sebanyak 20 orang sehingga total responden sebanyak 50 orang. Analisis data dengan Structural Equation Modelling (SEM) warpPLS. Audit operasional fungsi pemasaran dan pengendalian internal memiliki pengaruh terhadap efektivitas pelayanan sebesar $87 \%$. Hasil audit operasional memiliki hasil temuan di dalam audit operasional fungsi pemasaran yang dinyatakan closed oleh auditor kepada auditee yang artinya temuan tersebut telah memiliki solusi yang dapat meningkatkan kualitas pemasaran produk dan telah memiliki umpan balik positif dimana hasil tersebut berdampak positif pada efektivitas pelayanan konsumen. Bentuk pengendalian internal melalui aktivitas pengendalian dan pengawasan pada fungsi pemasaran yang telah diterapkan oleh pimpinan perusahaan meliputi pengendalian efektifitas program pemasaran melalui aktivitas dan pengawasan pemasaran, pengendalian strategi pemasaran yang dilakukan secara online dan offline, pegendalian keuntungan dan rentabilitas dalam kegiatan pemasaran dan pengendalian efisiensi pemasaran melalui personal selling yang dilakukan oleh sales di setiap outlet sehingga manajer pemasaran melakukan pengenalan pada setiap sumber pemasaran dalam meningkatkan prestasi marketing.
\end{abstract}

Kata Kunci: audit, efektivitas, madu, pelayanan, pemasaran, pengendalian

\begin{abstract}
The purpose of this study was to analyze the structural model of the effect of the operational audit of marketing and internal control functions on the effectiveness of customer service. Respondents in this study were marketing managers and staff in Malang and Palembang as many as 30 respondents and the administrative division in recording and auditors and auditees (which do not belong to the category of respondents 30 people) as many as 20 people so that the total respondents were 50 people. Data analysis using Structural Equation Modeling (SEM) warpPLS. The operational audit of marketing and internal control functions effects service effectiveness by $87 \%$. The results of operational audits have findings in operational audits of the marketing function that are declared closed by the auditor to the auditee, which means that the findings already have solutions that can improve the quality of product marketing and have positive feedback where the results have a positive impact on the effectiveness of customer service. Forms of internal control through control and supervision activities on the marketing functions that have been implemented by company leaders include controlling the effectiveness of marketing programs through marketing activities and supervision, marketing strategy control that was carried out online and offline, profit and profitability control in marketing activities and controlling marketing efficiency through personal selling conducted by sales at each outlet so that marketing managers make an introduction to each marketing source in improving marketing achievements.
\end{abstract}

Keywords: audit, control, effectiveness, honey, marketing, service 


\section{PENDAHULUAN}

Pembangunan di bidang peternakan merupakan sebuah solusi untuk menghadapi peningkatan kebutuhan protein hewani seiring dengan peningkatan jumlah penduduk dan kesadaran masyarakat untuk mengkonsumsi makanan yang mengandung nilai gizi tinggi. Sektor peternakan memberikan memiliki peran besar dalam mendukung peningkatan perekonomian nasional, karena pada dasarnya kebutuhan protein hewani yang tidak dapat digantikan dengan protein lainnya.

Pada era ekonomi kreatif dan arus globalisasi yang begitu kuat maka semua daya pesona meliputi pesona alam, sejarah dan budaya tentu tentu saja tidak dapat memberikan "value" bagi masyarakat jika tidak diimbangi dengan upaya menggugah minat pasar untuk mengunjungi serta menikmati berbagai objek wisata serta hasil industri kreatif bahkan arus informasi dan komunikasi yang terus berjalan dengan cepat pada generasi FANG (facebook, amazone, netflix dan google) sehingga sangat mendukung keberadaan ekonomi dan industri kreatif dalam melakukan pemasaran di lokasi pariwisata. Di antara usaha untuk menarik minat pasar itu adalah adanya karya industri pariwisata yang dilakukan secara berkala dan berkelanjutan serta berdaya saing tinggi baik di wilayah lokal maupun mancanegara melalui "Visit Indonesia Years" (Tahun Kunjungan Wisata) atau pameran kreativitas industri dan karya anak bangsa dari berbagai daerah dengan memperkenalkan dan mempromosikannya ke berbagai negara di dunia.

Upaya intervensi tersebut juga dilakukan oleh pemerintah kabupaten Malang, dimana kabupaten Malang merupakan kabupaten nomor dua terluas di Indonesia setelah kabupaten Banyuwangi sehingga hal tersebut merupakan salah satu peluang tinggi suatu wilayah untuk mengeksplore kekayaan pariwisata dalam suatu daerah. Kondisi kabupaten Malang dengan padat penduduk maka menjadikan wilayah potensi pariwisata adalah suatu sumber perekonomian, yang harapannya adalah pari-wisata yang berkelanjutan untuk menciptakan ekonomi dan lingkungan yang berkelanjutan dan dapat meningkatkan pendapatan suatu daerah.

Di Indonesia produksi madu baru mencapai sekitar 2000 ton/tahun dengan tingkat konsumsi madu perkapita masih rendah, yaitu sekitar $10 \mathrm{~s} / \mathrm{d} 15$ gram/orang atau hanya setara dengan satu sendok makan per orang per tahun
(Dirjen BPDASPS, 2013). Madu terkenal di dunia kesehatan karena mengandung banyak khasiat. Madu bisa dimanfaatkan sebagai obat, makanan, perawatan kecantikan, dan bumbu penyedap. Peningkatan pemasaran madu baik pada pasar domestik maupun pada pasar internasional akan menghadapi tantangan yang semakin kuat dalam era globalisasi.

PT Kembang Joyo Sriwijaya merupakan salah satu perusahaan yang bergerak pada bidang produksi berupa madu. Perusahaan yang berpusat di Palembang ini menyediakan produk madu dengan standart internasional dan juga madu lokal. PT Kembang Joyo Sriwijaya mulai membuka bisnis pada tahun 1998, yang kemudian belajar untuk menghasilkan produk madu dengan baik. Kembang Joyo juga belajar memahami berbagai aspek berternak lebah dan alasan mengapa berbagai teknik manajemen bekerja atau tidak bekerja secara optimal. Dari sinilah motto Kembang Joyo berasal yaitu "Scientific Beekeeping". Kembang Joyo menghasilkan produk perlebahan yang sesuai dengan standar mutu dengan menerapkan manajemen perlebahan yang baik dan higienis. PT Kembang Joyo Sriwijaya yang berkantor pusat di Jalan Jl. Raya Karang Juwet Donowarih No.101, Bonowarih, Karangploso, Kabupaten Malang. PT Kembang Joyo Sriwijaya menjual madu $100 \%$ asli dari peternakan lebah madu yang sangat dipercaya manfaatnya bagi kesehatan tubuh dan juga dapat dimanfaatkan untuk mengatasi luka bakar, menambah stamina, bahkan mencegah kanker. Produk yang tersedia terdapat beberapa pilihan jenis, ukuran dan rasa yang dapat disesuaikan dengan kebutuhan. Topografi Kabupaten Malang didominasi berbagai kawasan dataran tinggi dan perbukitan yang berlembah-lembah dan dataran rendah. Potensi wilayah di Kabupaten Malang yang membuat pemerintahan kabupaten memiliki peluang tinggi untuk menggali potensi daerah untuk dijadikan suatu bisnis yang menjanjikan sesuai dengan sumber daya yang ada, baik itu sumber daya manusia, sumber daya alam, iklim dan letak geografis yang ada di daerah tersebut. Beragam objek wisata baru, unik dan penuh dengan inovasi-inovasi yang belum pernah ada di Indonesia didirikan guna menarik wisatawan lokal maupun wisatawan asing.

Sasaran pemasaran madu Kembang Joyo sebagian besar adalah pada lokasi Pariwisata. Peluang inilah yang dimanfaatkan PT Kembang Joyo Sriwijaya dalam memasarkan produk mereka. Keahlian dan kepandaian para tenaga 
penjual dan bagian promosi diperlukan dan memegang peranan penting untuk memengaruhi konsumen agar mau membeli produk mereka.

Agar konsumen tidak merasa kecewa dengan produk yang mereka pilih diharapkan para tenaga penjual dan bagian promosi harus dapat menguasai dan memahami produk yang mereka jual untuk dapat menjawab pertanyaan konsumen saat akan membeli produk mereka. Para tenaga penjual dan bagian promosi juga harus pandai-pandai dalam hal promosi untuk dapat memikat konsumen yang banyak. Berdasarkan permasalahan tersebut. Disinilah peran manajer pemasaran dituntut aktif untuk mengintroduksi persiapan pengolahan produk sehingga semua kegiatan usaha perusahaan dapat terarah pada pencapaian tujuan dan sasaran perusahaan tersebut yang dinamakan proses audit di dalam fungsi pemasaran. Menurut Tunggal (2003), terdapat tiga faktor dalam mempengaruhi kinerja suatu pasar secara langsung, yaitu posisi pasar organisasi, sifat dari peluang dan ancaman, lingkungan organisasi dan kemampuan organisasai dalam mengatasi sebuah masalah. Fungsi utama audit operasional atas fungsi pemasaran adalah menguji dan menilai tujuan dari kebijakan pemasaran, serta melakukan penelaahan dalam peluang-peluang yang dapat didapatkan sehingga tujun perusahaan dapat tercapai.

\section{MATERI DAN METODE}

Pelaksanaan penelitian dilakukan di PT. Kembang Joyo Sriwijaya yang merupakan perusahaan yang bergerak dalam budidaya madu sampai dengan pengolahan menjadi produk madu di Kabupaten Malang. Metode penelitian menggunakan survei untuk mendapatkan data primer dan data sekunder. Responden dalam penelitian ini adalah manajer pemasaran dan karyawan serta sales yang berada di masingmasing outlet yang ada di wilayah Malang serta Palembang sebanyak 30 responden dan divisi administrasi dalam recording serta auditor dan auditee (yang tidak termasuk kategori responden 30 orang) sebanyak 20 orang sehingga total responden sebanyak 50 orang.

Variabel pengamatan terdiri dari variabel bebas dan terikat. Variabel bebas meliputi audit operasional (X1) yang terdiri dari dimensi variabel kualifikasi auditor (x1.1), tujuan audit operasional (x1.2), manfaat audit operasional (x1.3), pelaksanaan audit (x1.4), hasil audit operasional (x1.5); Pengendalian Intern (X2) terdiri dari lingkungan pengendalian (x2.1), aktivitas pengendalian (x2.2), manajemen resiko (x2.3), sistem komunikasi dan informasi akuntansi (x2.4), dan pengawasan (x2.5) ;Efektivitas Pelayanan Publik (Y) terdiri dari waktu pelayanan (y1), kecermatan pelayanan (y2), manajemen layanan (y3).

Teknik pengumpulan data menggunakan wawancara, kuesioner, dan dokumentasi. Analisis data menggunakan analisis SEM dengan software warpPLS yang merupakan salah satu jenis persamaan struktural halus yang bersifat rekursif dan meruapakan analisis varian sehingga tujuan utama dalam penelitian ini adalah mengembangkan sebuah kejadian bahkan kejadian tersebut bisa saja di luar dugaan penulis karena varian dalam hasil analisis tersebut beragam tidak seperti CB-SEM analisis kovarian, maka hal tersebut merupakan salah satu alasan penulis menggunakan analisis warpPLS (Ghazali \& Latan, 2014).

Analisis data yang digunakan dalam penelitian ini adalah structural equation modelling (SEM) dengan menggunakan software warpPLS. Analisis SEM merupakan analisis multivariat yang digunakan untuk mengetahui pengaruh audit operasional dan pengendalian internal terhadap efektivitas pelayanan konsumen PT Kembang Joyo Sriwijaya.

Analisis SEM menggunakan persamaan struktural yang terdiri dari variabel eksogen yang terdiri dari audit operasional (X1) dan pengendalian intern (X2) sedangkan variabel endogen adalah Efektivitas pelayanan publik konsumen produk PT. Kembang Joyo Sriwijaya (Y) dalam penelitian tidak memiliki variabel intervening yang menghubungkan antara variabel eksogen dengan variabel endogen. Berikut merupakan bentuk model persamaan struktural regresi:

Efektivitas pelayanan publik $=\beta \mathrm{K}$ audit operasional $+\beta$ pengendalian intern

Langkah-langkah analisis SEM dengan metode PLS, dimana proses pertama yang dilakukan adalah menganalogi ilmu yang terkait atau berkaitan dengan ilmu lain; merancang puter model dengan meihat hubungan variabel manifest yang menghasilkan hubungan formatif dan reflektif; merancang struktur permodelan dalam diagram jalur; mengkonversikan diagram jalur ke persamaan; pendugaan parameter melalui estimasi jalur yang menghubungkan antara variabel laten, hubungan variabel laten 
dengan variabel manifest; outer model untuk melihat signifikansi; inner model untuk melihat besarnya pengaruh variabel endogen dalam model; pengujian hipotesis; asumsi model yang bertujuan untuk menginterpretasikan model struktural dari masing-masing variabel (Ghazali dan.Latan.2014)

\section{HASIL DAN PEMBAHASAN}

Berdasarkan hasil analisis data yang dilakukan bahwa pengaruh dan model dari pengaruh audit operasional dan pengendalian internal terhadap efektivitas pelayanan konsumen pada PT. Kembang Joyo Sriwijaya adalah sebesar 0,868 atau $87 \%$ sisanya $13 \%$ di pengaruhi oleh variabel lain di luar penelitian audit dan pengendalian perusahaan. Hasil audit yang dilakukan rutin setiap tahun memberikan dampak positif terhadap konsumen, begitu pula aktivitas pengendalian di dalam tahap produksi, pemasaran dan keuangan di PT. Kembang Joyo Sriwijaya memberikan kontribusi positif terhadap efektivitas pelayanan konsumen dari sudut pandang waktu pelayanan yaang tepat dalam kegiatan pemasaran dan relevansinya dengan kegiatan produksi dan keuangan. Berikut merupakan mode hasil pengaruh auidt operasional dan pengendalian internal perusahaan terhadap efektifitas dalam melayani konsumen berdasarkan waktu.

Berdasarkan hasil analisis data untuk mengetahui model dan pengaruh maka audit operasopnal dan pengendalian internal memiliki pengaruh sebesar 87\% terhadap efektivitas pelayanan publik. Model persamaan struktural analisis WarpPLS adalah sebagai berikut:

$$
\mathrm{Y}=0,288 \mathrm{X} 1+0,265 \mathrm{X} 2
$$

Hasil audit mewakili dimensi variabel audit operasional sebesar 0,288 yang artinya meningkatnya hasil audit operasional lengkap dan closed pada setiap temuan yang dilakukan oleh auditor kepada auditee di bidang pemasaran oleh staff di PT. Kembang Joyo Sriwijaya sebesar 1 unit maka mampu meningkatkan efektivitas pelayanan publik sebesar 0,288 , hal tersebut dikarenakan banyaknya temuan di dalam audit operasional fungsi pemasaran yang dinyatakan closed oleh auditor kepada auditee yang artinya temuan di dalam audit operasional fungsi pemasaran yang dinyatakan closed oleh auditor kepada auditee yang artinya temuan tersebut telah memiliki solusi dan dalam proses solusi yang dapat meningkatkan kualitas pemasaran produk PT. Kembang Joyo Sriwijaya dan telah memiliki umpan balik positif. Beberapa temuan yang dilansir di dalam proses audit operasional fungsi pemasaran yang berkaitan dengan basic customer relation adalah perusahaan minimal harus memiliki kebijakan tertulis yang berkaitan dengan aspek pemasaran antara lain tujuan pemasaran perusahaan yang utama adalah meningkatkan kepuasan konsumen sehingga perusahaan madu milik Kembang Joyo lebih mengutamakan kualitas madu alami yang dapat dijaminkan oleh perusahaan dengan memberikan garansi sebesar Rp 1.000.000 setiap botol apabila ditemukan madu tidak asli dengan merk perusahaan Kembang Joyo Sriwijaya sehingga konsumen dapat mendapat-kan produk madu asli tanpa meragukan kualitas dan keaslian madu tersebut sesuai dengan brand dan motto keaslian sebuah produk.

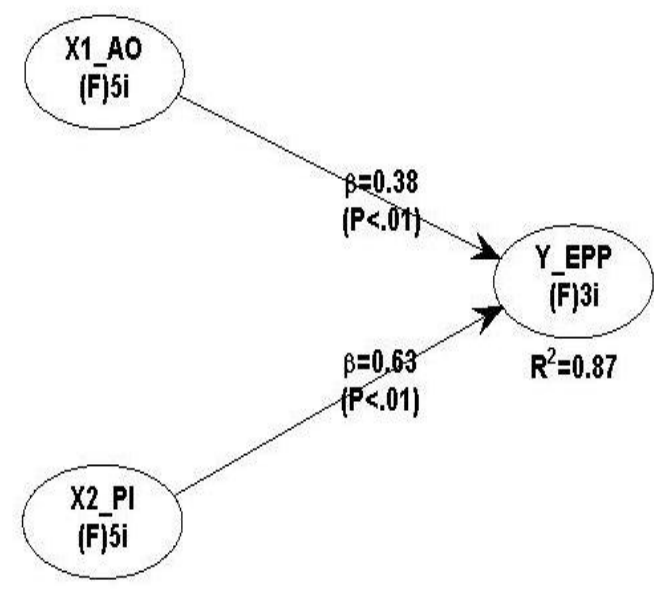

Gambar 1. Model pengaruh audit operasional dan pengendalian internal terhadap efektivitas pelayanan publik

Merek dibangun berdasarkan kombinasi benefit yang diberikan produk tersebut dengan karakter dari ekuitas merek (Freddy, 2008). Kebijakan yang dimiliki oleh perusahaan disajikan dalam bentuk dokumen antara lain kebijakan yang dibuat untuk mengiringi alur proses pemasaran, kebijakan untuk kualifikasi dan aturan sumberdaya manusia dalam bidang pemasaran, kebijakan penjaminan keamanan produk hingga produk sampai ke tangan konsumen akhir sesuai dengan kualitas dan kuantitas yang diharapkan. Kebijakan tersebut dimuat di dalam dokumen penjaminan yang dilampirkan beberapa data dukung terkait dengan standar operasional prosedur untuk pegawai dan pimpinan di dalam proses pemasaran serta hasil dari proses audit yang 
dilaksanakan rutin setiap akhir tahun untuk melihat feedback konsumen terhadap produk dan pelayanan di dalam fungsi pemasaran yang berkontribusi terhadap peningkatan revenue perusahaan. Perusahaan harus mennggali informasi data konsumen yang bersifat sustainable mengingat produk kompetitor yang mulai bermunculan.

Wijayanti (2010) bahwa penerapan audit operasional menghasilkan temuan-temuan audit operasional yang menunjukkan adanya ketidakefektivitas sistem pemasaran serta pengendalian internal pada sistem pemasaran suatu organisasi. Hasil penerapan audit operasional adalah temuan-temuan audit operasional dan rekomendasi kepada pihak-pihak manajemen untuk memecahkan masalah dan memperbaiki pengendalian internal yang telah ada dan operasi sistem pemasaran suatu organisasi.

Persiapan yang dilakukan oleh perusahaan dalam proses audit oleh auditor eksternal dan internal kepada auditee (karyawan di bidang pemasaran seluruh outlet di Malang dan Palembang serta sales dan beberapa divisi keuangan yang berkontribusi dalam pemasaran produk) yang pertama adalah menyiapkan dokumen pendukung penjaminan terutama adalah kejelasan manajemen perintah di dalam proses pemasaran, maka PT. Kembang Joyo Sriwijaya memiliki kejelasan struktur organisasi dalam menjaminkan kejelasan proses perintah dalam manajemen sehingga di dalam struktur tersebut proses organizing jelas maka korelasi setiap staf divisi pemasaran dengan divisi lainnya mampu terstruktur, maka struktur organisasi dinilai sangat penting saat proses audit berlangsung dan auditor menyatakan closed. Dokumen kebijakan yang dimiliki oleh PT Kembang Joyo Sriwijaya berkaitan dengan kebijakan harga sehingga antara wilayah Malang dan wilayah Palembang memiliki kebijakan yang berbeda-beda sesuai dengan Upah Minimum Regional setiap wilayah berdasarkan kebijakan harga dan pendapatan per kapita di wilayah tersebut walaupun produk madu samasama diproduksi di wilayah Malang. Metode penentuan harga dilakukan berdasarkan harga raw material, UMK, pendapatan per kapita dan permintaaan konsumen akan produk madu serta pasar (sehingga dalam pemasaran produk peternakan berlakunya hukum cateris paribus).

Pasar merupakan change driver yang dapat merubah sistem ekonomi nasional berdasarkan adaptasi terhadap situasi global (Kartajaya, 2006). Pasar akan bertambah luas sehingga dapat lebih mudah dimasuki pesaing baru bagi perusahaan. Selain itu, struktur dan sensivitas pasar dapat memacu pesaing untuk meningkatkan ragam strateginya. Struktur dan perilaku pasar dapat berubah terkait dengan kemajuan teknologi dan sistem perkonomian.

Aktivitas pengendalian dan pengawasan di dalam proses manajemen memberikan pengaruh positif terhadap efektivitas pelayanan publik masing-masing bernilai sama dengan beta koefisien sebesar 0,265 yang artinya adalah semakin sering sistem pengendalian internal yang dilakukan oleh pihak perusahaaan dalam mengevaluasi tugas marketing dan divisi keuangan kemudian pihak pengendali melakukan pengolahan informasi yang diterima dari lapang sehingga perlu analisis data informasi yang diterima karena berkaitan dengan layanan konsumen serta pembagian kekuasaan dan wewenang serta tugas masing-masing divisi secara jelas dan terukur maka akan meningkatkan efektivitas pelayanan konsumen, selain itu di dalam pengendalian internal PT. Kembang Joyo Sriwijaya yang berdampak terhadap efektivitas pelayanan konsumen adalah kegiatan pengawasan dimana pimpinan perusahaan sebagai auditor internal yang memperhatikan hasil audit dan review mengenai temuan yang bersifat masih open sehingga akan dicarikan solusi maka dengan adanya solusi dan pelaksanaan membuat temuan tersebut closed dan yang paling penting proses audit dilaksanakan setiap tahun karena merupakan kegiatan rutin perusahaan yang tergolong pada annual program, sehingga semakin meningkatnya aktivitas dan penga-wasan di dalam pengendalian internal sebesar 1 unit maka akan meningkatkan efektivitas pihak marketing dalam berhadapan dengan konsumen sebesar 0,265 unit. Proses pengendalian internal yang dilakukan oleh pimpinan perusahaan yang melakukan proses auditing dengan memetakan lingkungan pemasaran berdasarkan beberapa faktor antara lain faktor ekonomi, politik, hukum, perkem-bangan teknologi pada saat mendekati konsumen di era revolusi industri 4.0 serta pangsa pasar dalam menghadapi beragam perilaku, permintaan, kebutuhan, dan keinginan produk madu dari konsumen. Bentuk pengendalian internal pada fungsi pemasaran yang telah diterapkan oleh pimpinan perusahaan meliputi pengendalian efektifitas program pemasaran melalui aktivitas dan pengawasan pemasaran, pengendalian strategi pemasaran yang dilakukan baik secara online 
dan offline, pegendalian keuntungan dan rentabilitas dalam kegiatan pemasaran produk madu dan pengendalian efisiensi pemasaran melalui personal selling yang dilakukan oleh sales di setiap outlet madu kembang joyo sehingga manajer pemasaran melakukan pengenalan pada setiap sumber pemasaran dalam meningkatkan prestasi marketing. Langkah yang ditempuh oleh manajer pemasaran antara lain menentukan material proses pengendalian yang akan di audit pada annual program, menentukan standar produk pada sudut pandang konsumen berdasarkan kebutuhan dan keinginan serta permintaan, mengukur kinerja pemasaran berdasarkan dokumen SOP, menentukan beberapa temuan yang mengakibatkan dari beberapa penyimpangan serta melakukan tindakan koreksi sehingga auditor dapat menyatakan temuan closed.

Pengumpulan informasi audit pendahuluan khususnya pada departemen sales and marketing mencangkup hal yang cukup luas, pencarian tidak dapat hanya terpaku pada pelaksanaan standar perusahaan dan peraturan terbaru, namun juga pada pihak yang berkepentingan dalam pelaksanaan tujuan utama perusahaan yang dibebankan pada departemen sales dan marketing, yakni pendapatan perusahaan berwujud target quantity penjualan. Pelaksanaan yang dapat dilihat melalui hasil audit yang dilakukan oleh auditor perusahaan hanya mencangkup pada pelaksanaan internal sesuai dengan SOP (Dhanti et al.,2015)

Berdasarkan sudut pandang ekonomi, dimana pada saat mengalami inflasi maka akan berdampak terhadap nilai suatu barang di dalam negeri maka di dalam proses pengendalian internal perusahaan mengambil beberapa strategi untuk tetap mempertahankan jumlah pelanggan melalui program diskonto yang dilakukan di beberapa outlet terutama di outlet yang berlokasi di kawasan wisata dengan pangsa pasar yang telah disesuaikan sehingga berdasarkan hasil audit proses tersebut dikategorikan efektif dari segi elayanan konsumen. Pada sudut pandang politik dan hukum kebijakan pemerintah menentukan harga produk pertanian salah satunya adalah madu, dimana kedua faktor tersebut dipengaruhi oleh fenomena peningkatan impor produk pertanian yang mengakibatkan turunnya produktivitas produk pertanian di dalam negeri menurun bahkan kehilangan konsumen karena harga impor relatif lebih murah. Upaya yang dilakukan oleh perusahaan dalam meningkatkan jumlah konsumen di tengah banyaknya ketimpangan yang terjadi di era ekonomi kreatif sektor agribisnis maka salah satunya adalah meningkatkan pelayanan dan komunikasi dengan konsumen melalui media sosial. Media sosial menjadi sebuah daya tarik bagi konsumen yang ingin mendapatkan produknya secara praktis sehingga kontinyuitas dari sebuah produk terjamin, bahkan dengan adanya sosial media maka produsen dapat memperluas pangsa pasar. Beberapa segmen pasar untuk wilayah pemasaran di kota Palembang mampu memberikan keuntungan salah satunya di kota Batam yang bebas PPN.

Variabel segmentasi utama yang digunakan untuk pasar konsumen adalah geografi, demografi, psikografi, perilaku dan individual (Kotler, 2005). Semakin tingginya tingkat persaingan suatu industri, menuntut perusahaan untuk menggunakan variabel yang paling dekat dengan perilaku pembelian yaitu behavioral (perilaku) atau individual.

\section{KESIMPULAN}

Audit operasional fungsi pemasaran dan pengendalian internal memiliki pengaruh terhadap efektivitas pelayanan publik sebebsar $87 \%$. Hasil audit operasional memiliki hasil temuan di dalam audit operasional fungsi pemasaran yang dinyatakan closed oleh auditor kepada auditee yang artinya temuan tersebut telah memiliki solusi dan dalam proses solusi yang dapat meningkatkan kualitas pemasaran produk PT. Kembang Joyo Sriwijaya dan telah memiliki umpan balik positif dimana hasil tersebut berdampak positif pada efektivitas dalam pelayanan konsumen.

Bentuk pengendalian internal melalui aktivitas pengendalian dan pengawasan pada fungsi pemasaran yang telah diterapkan oleh pimpinan perusahaan meliputi pengendalian efektifitas program pemasaran melalui aktivitas dan pengawasan pemasaran, pengendalian strategi pemasaran yang dilakukan baik secara online dan offline, pegendalian keuntungan dan rentabilitas dalam kegiatan pemasaran produk madu dan pengendalian efisiensi pemasaran melalui personal selling yang dilakukan oleh sales di setiap outlet madu kembang joyo sehingga manajer pemasaran melakukan pengenalan pada setiap sumber pemasaran dalam meningkatkan prestasi marketing. 


\section{DAFTAR PUSTAKA}

Dhanti,Y.S., D. Atmojo, \& Jaswadi. 2015. Analisis audit operasional fungsi pemasaran (studi kasus pada PT. Pardic Jaya Chemicals). Jurnal Administrasi Bisnis 23(1).

Dirjen BPDASPS. 2013. Tingkat Konsumsi Madu Indonesia. Ditjen Bina Pengelolaan Daerah Aliran Sungai dan Perhutanan Sosial. Jakarta.

Freddy. R. 2002. Creating Effective Marketing Plan, Teknik Membuat Rencana Pemasaran Berdasarkan Customer Values dan Analisis Kasus. Gramedia. Jakarta.

Ghazali, I \& Latan. 2014. Partial Least Square Konsep, Metode dan Aplikasi Menggunkaan Program WarpPLS 5.0. Badan Penerbit Universitas Diponegoro. Semarang.
Kartajaya. 2006. Marketing Plus 2000, Siasat Memenangkan Persaingan Global. Gramedia. Jakarta.

Kotler, P. 2005. Manajemen Pemasaran Jilid 1. Gramedia. Jakarta.

Tunggal, A.W. 2000. Audit Manajemen Kontemporer. Edisi Revisi. Havarindo. Jakarta.

Uli, L.P. 2008. Audit Pemasaran Pada PT. Godongijo Asri di Sawangan, Depok, Jawa Barat. Institut Pertanian Bogor. Bogor.

Wijayanti, D.E. 2010. Implementasi Audit Operasional pada Fungsi Pemasaran Guna Mengevaluasi Efektivitas di Hotel The Graha Cakra Malang. Tesis. Fakultas Bisnis dan Ekonomika Universitas Surabaya. http://digilib.ubaya.ac.id/data_ pustaka-154889.html 